\title{
Editorial
}

\section{Onde as coisas talvez sejam o que não deveriam ser}

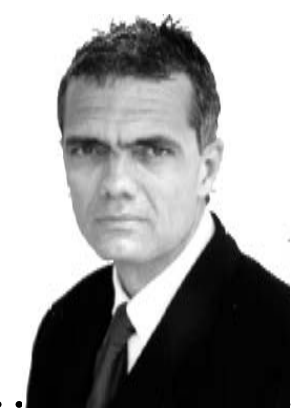

Marco Antonio Guimarães da Silva marco@atlanticaedu.com.br

\section{"Meu querido amigo,}

Se você e eu tivéssemos comparecido à eleição da chefatura poderíamos ter posto a nossa conversa em dia. Soube que as extensas e intermináveis filas, geradas pela des- organização vigente, puseram de castigo os milhares de eleitores, obrigando-os a perder, sob uma temperatura de 30 graus negativos, preciosas horas de seus escassos tempos......"

Talvez Igor Petronsvsky tivesse exagerado. Estava frio, nevava, mas a temperatura não alcançava os trinta negativos, talvez vinte, vinte e cinco no máximo, daí não passava. A carta era extensa e, à medida que as letras se juntavam para formar as palavras, ficava clara a implicância e a impaciência dele com a bizarra democracia do sistema que o obrigava a votar. Essa coação do voto o lembrava, a cada eleição, o subdesenvolvimento de sua província. Não, ele não deixara de votar porque discordava das regras estabelecidas; uma gripe o derrubara. Estivesse em boas condições, iria; a contragosto, mas iria. Pela primeira vez, ele se importava com os resultados de uma eleição e torcia para mudanças e para a vitória da oposição.

O seu contentamento foi grande ao saber do resultado promulgado. A sua expectativa fora alcançada e a sua ansiedade aplacada. Ele tinha o receio de ver a sua preferência eleitoral ser vencida pela diferença de um único voto: o seu. Os comissários eleitorais reconheceram a vitória da oposição e lavraram a ata. "Viva a democracia: rei posto, rei morto", pensou ele. Pensou, mas pensou errado. Dias após, telefona-lhe um amigo com a noticia de que o grupo perdedor havia solicitado a anulação da eleição. "Mas que diabos está acontecendo?", pergunta
Igor Petronsvsky para o seu interlocutor telefônico. "O grupo derrotado não havia reconhecido a derrota?”, continua. "Parece que havia, mas, meu caro Petronsvsky, sabemos bem o quão difícil é largar o poder, diz o seu amigo. "É verdade; a síndrome de abstinência que vem para algumas pessoas viciadas por esse poder pode ser pior do que a sofridas por aqueles que tentam deixar vícios de drogas pesadas", diz Igor.

Tenta ainda buscar explicaçóes para o ocorrido e lembra, então, da obra de Maquiavel dirigida a Lorenzo de Medicis. O livro fora escrito nos últimos meses do ano de 1513, na Vila de San Casciano, por um Maquiavel no ostracismo, com a finalidade de determinar qual era a essência dos estados, quantas classes esses estados tinham e como essas classes eram adquiridas, mantidas e enfim perdidas. Igor Petronsvsky nele encontra o amparo para entender o estado real das "coisas", quando se depara com um trecho que contem a máxima do maquiavelismo: o uso da força e da astúcia, a teoria da simulação e dissimulação, "um príncipe não necessita ser virtuoso, basta-lhe apenas simular sê-lo, sem precisar cumprir a palavra dada; o fim justifica os meios."

Igor Petronsvky torce para que o estado real das "coisas" reconheça a vitória do grupo já declarado vencedor. Ele teme que, se a democracia e justiça forem vencidas, as "coisas" podem vir a ser o que não deveriam ser.

Nota: os personagens e fatos aqui citados fazem parte de um universo ficcional e não devem ser comparados a situaçôes, a pessoas ou instituiçóes da vida real. 